\title{
ACTIVATE READING COMPREHENSION OF SECOND LANGUAGE ACQUISITION (SLA) BY APPLYING KNOW-WANT TO KNOW-LEARNED (KWL) STRATEGY
}

\author{
Adieli Laoli \\ IKIP Gunungsitoli, Indonesia \\ (laoliadieli65@gmail.com)
}

Received: $05^{\text {th }}$ June 2021; Revised: $28^{\text {th }}$ October 2021; Accepted: $27^{\text {th }}$ December 2021

\section{ABSTRACT}

The purpose of this research is to describe how students achieve their reading comprehension performance when they apply the KWL (Know, Want to Know, Learned) Strategy. KWL is a strategy that can better comprehend the content of material read by the students. Using this strategy can help the students read effectively and efficiently to build their comprehension. After analyzing the data, the finding shows that the KWL Strategy positively contributes to the students' achievement in their reading comprehension. It can be seen from the progress of scores in each cycle that the students acquired. Other aspects that the students should have in applying this strategy, such as motivation and vocabulary mastery, play a vital role in classroom activities; besides, the serious attention of the teacher to use the procedures of KWL strategy is necessary. The result of this research is KWL strategy can increase the students' reading comprehension in Second Language Acquisition (SLA) subject by applying some modifications to the procedures. Considering the result from the research, the researcher recommends that the KWL strategy be continuously implemented in activating students' reading comprehension.

Key Words: KWL strategy; motivation; reading comprehension; students' achievement; vocabulary mastery

\section{ABSTRAK}

Tujuan dari penelitian ini adalah untuk mendeskripsikan bagaimana siswa mencapai pemahamannya ketika menerapkan Strategi KWL. KWL merupakan salah satu strategi yang dapat memberikan pemahaman yang lebih baik akan sebuah konten materi yang dibaca oleh siswa. Penggunaan strategi dapat membantu siswa membaca secara efektif dan efisien untuk membangun pemahaman. Hasil analisis data menunjukkan bahwa Strategi KWL memiliki kontribusi positif terhadap prestasi siswa dalam memahami bacaan SLA, hal ini dapat dilihat dari kemajuan akan nilai dalam pembelajaran yang diperoleh siswa. Aspek lain yang harus dimiliki siswa dalam menerapkan strategi ini, misalnya motivasi dan penguasaan kosakata memegang peranan yang sangat penting dalam kegiatan kelas, selain itu perhatian serius dari guru untuk menerapkan prosedur strategi KWL mutlak diperlukan. Hasil dari penelitian ini menunjukkan bahwa strategi KWL dapat meningkatkan pemahaman membaca siswa pada pelajaran SLA dengan penerapan beberapa modifikasi pada prosedurnya. Berdasarkan hasil penelitian tersebut, peneliti merekomendasikan strategi KWL untuk diimplementasikan secara berkelanjutan untuk meningkatkan pemahaman membaca siswa.

Kata Kunci: strategi KWL; motivasi; pemahaman membaca; prestasi siswa; penguasaan kosakata

How to Cite: Laoli, A. (2021). Activate Reading Comprehension of Second Language Acquisition (SLA) By Applying Know-Want to Know-Learned (KWL) Strategy. IJEE (Indonesian Journal of English Education), 8(2), 179-197. doi:10.15408/ijee.v8i2.20910 


\section{INTRODUCTION}

Reading is a source of learning and a source of enjoyment. Someone may travel around the world through reading. They may read the story of a country, for example, what happens to the country, how the societies get a living, how the government manages the economic activities, how the education owned by the societies, what the government does to promote the tourism destination, what the government does to defend his country from outside enemy, etc. All this information may be read from books, magazines, newspapers, and online devices, for example, the internet, Facebook, Instagram, and WhatsApp.

According to Akyol (2013), reading is the process of establishing meaning in a suitable environment using appropriate information based on effective communication between the author and the reader by the appropriate aim and method. In line with this, Castles et al. (2018) define that reading is the basis for the acquisition of knowledge, cultural engagement, democracy, and success in the workplace. Reading activities allow someone to enhance their knowledge and change their mind to see the world.

In reading, it is necessary to engage the students to set the goal to grow their motivation. Protacio (2017) implied that reading engagement represents the students' motivation to read and engage in reading activities to improve their understanding of texts. Hence, the current study provides evidence regarding reading engagement and comprehension level efficacy.

Establishing meaning, understanding, and acquisition of knowledge refers to the comprehension of the text that the readers should build. Glenberg (2017) asserts that comprehension accounts for the ability to engage in responses to the information provided in the text. Next, comprehension means different things to different people. Indeed, comprehension is not a unitary phenomenon but rather a family of skills and activities (Kintsch, W., \& Kintsch, 2005; Rapp \& van den Broek, 2005; Van den Broek et al., 2005)

Reading comprehension is the process through which the readers are interacting with written text to get the meaning. According to Oakley (2011), reading comprehension is the desired result of reading and can be defined as the skill of combining background knowledge with reading texts. Then, Snow (2002) defines reading comprehension as the process of simultaneously extracting and constructing meaning through 
interaction and involvement with written language.

Castles et al. (2018) emphasized that the goal of reading comprehension is to understand what has been read. Thus, reading development must be to develop a system that allows students to construct meaning from print. On the other hand, the students are expected to describe, explain, and address the content they have acquired. Then, reading comprehension is essential that the students can effectively comprehend the text to succeed in their academic and professional objectives at the global level (Meniado, 2016). Therefore, developing reading comprehension ability is an important aspect of the acquisition of a second language. Second Language Acquisition (SLA) is the subject that should be studied by the students of the sixth semester of English Department IKIP Gunungsitoli.

From the target above, the students found difficulties comprehending the material provided in the reference book (Escudero, 2018). A student who starts college education may face many challenges related to reading due to the lack of reading culture, which has been evidenced in Ecuador since early childhood and throughout basic education and high school. The same situation may be the same as the sixth- semester students of English Department IKIP Gunungsitoli to comprehend the material of SLA. The students found problems to make connections between parts of the passage to build up an interpretation requires recognition of the words, the students cannot hold information in mind, the students cannot scan backward, and forwards to relevant words and phrases, the students are not able to understand of cues from sentence structure, those problems influence their comprehension from the content of SLA.

To overcome the problems, the researcher applies the KWL (Know, Want, Learned) strategy in teaching SLA because many results of research suggest that KWL strategy can give a better result to comprehend the content of the material read by the students. For example, Kadhim (2019) found that KWL strategy is a good strategy which enables the students to activate their knowledge and operate their thinking to memorize their information besides the students are more active and participate while the process of learning. This opinion inspired the researcher to conduct research with the title, Activate Reading Comprehension of Second Language Acquisition (SLA) by Applying KWL Strategy. 
According to Torgesen (2000), reading comprehension is influenced by a broad range of factors, including their motivation, interest, vocabulary, general knowledge, knowledge of the particular subject, word identification skills, reasoning ability, use of effective strategies to identify main ideas and supporting detail, and an appreciation of text structure. It is expected that the students of the sixth semester of the English Department have mastered all these factors as the prerequisite of comprehending the SLA subject. At the end of the students' activities, they can comprehend their reading material. Westwood (2001) stated that the readers must use the acquired information to filter, interpret, organize, reflect upon, and establish relationships with the new incoming information on the page.

Therefore, the sixth-semester students of the English department are expected to achieve competence, as stated by Westwood. As stated previously, the book used by the students is Introducing Second Language Acquisition, which was written by Troike (2012). The topics that have to be studied consist of seven chapters: Chapter I: Introducing Second Language Acquisition, Chapter II: Foundations of Second Language Acquisition, Chapter III: The linguistics of Second Language Acquisition, Chapter IV: The Psychology of Second
Language Acquisition, Chapter V: Social Contexts of Second Language Acquisition, Chapter VI: Acquiring Knowledge for L2 Use, Chapter VII: L2 Learning and Teaching. Those materials are studied by using KWL Strategy

The KWL strategy is used to activate the students' background knowledge. The students build selfconfidence to plan and monitor their comprehension until they can link the new information they get to have the means of learning. Hashimi and Delemi (2008) and Nofal (2007), as quoted by Alsoudi (2017), indicated that the KWL strategy provokes students thinking by asking questions, independent thinking, and setting objectives that lead them to achieve their goal. According to $\mathrm{Vy}$ and $\mathrm{Ha}$ (2020), the KWL strategy was proven to improve the students' reading comprehension achievement as it could aid the students in dealing with some difficulties. Kadem (2020) also recommends implementing the KWL strategy in their sessions to raise the students' abilities to understand what the students read and ensure class enjoyment and effectiveness.

Furthermore, Aseeri (2020) contends that KWL Strategy refers to a metacognition strategy that has three steps. The first step is deputized by the letter $(\mathrm{K})$ to show what the learner 
knows about the subject matter. The second step is deputized by the letter (W) to show what the learner seeks to learn or acquire. The third step begins with the letter (L) to show what the learner has learned and how much they have an advantage from the teaching topic. Then, Thi Thanh Dieu (2015) explained that the KWL strategy helps teachers activate learners' schema concerning a topic or subject. It promotes research, active reading, and inquisition since Schema theory can be a beneficial theory that helps us understand how our brain processes information. The research had been done by Mustafa and Muhammad (2016) gave evidence that the experimental group who taught using K.W.L had higher achievement than the control group. Backman (2006, p. 79) also indicates that the K-W-L technique is a good strategy because it enables the teacher to assess students' background knowledge and interests before the lecture and easily understand to monitor the content of the material they have learned. In line with some previous research, Al-wazzan (2020) reveals that teaching reading skills based on the KWL strategy positively influence students. From the findings above, the researcher believed that KWL Strategy might contribute to the sixth-semester students of the English Department of IKIP Gunungsitoli.
The researchers have found some procedures, for example, Youniss (2013), Dieu (2015), and Alsoudi (2017).

a. Youniss (2013) applied the KWL strategy in three steps: before reading while reading and after reading

\section{Before Reading}

1. Preparing the text.

2. The teacher is drawing three columns on the board, stating on the first column:

\begin{tabular}{|c|c|c|}
\hline \multicolumn{3}{|c|}{ TITLE OF THE TEXT } \\
\hline $\begin{array}{l}\text { What do I } \\
\text { know } \\
\text { about the } \\
\text { subject }(\mathrm{K})\end{array}$ & $\begin{array}{l}\text { What I } \\
\text { want to } \\
\text { know } \\
\text { about the } \\
\text { subject (W) }\end{array}$ & $\begin{array}{l}\text { What I } \\
\text { learned }(\mathrm{L})\end{array}$ \\
\hline $\begin{array}{l}\text { 3. The } \\
\text { disc } \\
\text { retri } \\
\text { kno } \\
\text { (bra }\end{array}$ & $\begin{array}{l}\text { acher ask } \\
\text { with ea } \\
\text { their abou } \\
\text { torming). }\end{array}$ & $\begin{array}{l}\text { students to } \\
\text { other and } \\
\text { previous } \\
\text { the subject }\end{array}$ \\
\hline
\end{tabular}

4. Teacher makes the students ask questions about what they want to know about the subject and record these questions in the second column (W).

While-Reading (Reading and discussing the text)

1. Reading the subject: the student has to be the model for the reading. 
2. Letting students read every paragraph silently. In this case, students should read

3. carefully to find the answers to the questions in the second column (W).

4. Assigning some students to read the text aloud.

After Reading (Reading and Discussing the Text)

1. Discussion of the text which has been read - what is in the first and second columns. Then ask them to write what they have learned for the text in the third column (L).

2. Encourage students to write any interesting thing they found while reading the text in the third column.

3. Encourage students to refer to other sources to answer any difficult question from the second column.

4. Discussing the answers which are written in the third column by students.

b. Dieu (2015)

1. Pre-Activity: Train students to collect their schema and find out their lack of info

2. Main-Activity.
3. Post-Activity.

c. Alsoudi (2017).

1. Clarifying the topic: by writing the lesson title on the board.

2. Determination of the previous knowledge needed for the new knowledge $(\mathrm{K})$.

3. What I want to know (W); the teacher should determine the instructional objectives of the lesson.

4. Reading comprehension: The students have to read and understand the new topic.

5. Post-reading: students start reflecting on what they understand, and ask questions about what they need to know (L).

6. Evaluation: students start to evaluate what they knew and understood.

The procedures above became a consideration for the researcher to apply the KWL Strategy in the classroom by doing some modification from them. It could be as follows:

\section{Pre Reading}

1. The researcher decided the topic that is studied

2. The researcher drew three columns on the board as follow 


\begin{tabular}{l|l|ll}
\hline \multicolumn{4}{l}{ TITLE OF THE TEXT } \\
\hline WHAT I & WHAT I & WHAT I \\
KNOW & WANT & LEARN \\
$($ K) & TO & (L) \\
& KNOW & \\
& (W) & \\
\hline
\end{tabular}

3. The researcher activated the students' prior knowledge by asking words, phrases, and questions and their answers they wrote in column $\mathrm{K}$.

4. The researcher invited the students to discuss the answers to the questions.

\section{Whilst Reading}

1. The researcher allowed the students to read their text, and the students focused on getting the main idea on their text.

2. The researcher asked the students to write some questions with (what, who, why, when, where, which, whose, whom, and how), and the questions were written in column W.

3. The researcher gave the time for the students to find the answer to the questions, and the answers would be written on column L.

\section{Post Reading}

1. The researcher invited the students to discuss what information they got in column
L by choosing some of the students.

2. The researcher asked the students to convey their idea orally to develop their speaking ability.

3. The researcher gave the time for the students to write If they had other interesting information in column L.

4. The researcher encouraged the students to find other sources related to the topic to develop their knowledge.

\section{METHOD}

\section{Research Design}

This research was conducted by using classroom action research (CAR). Action research is a methodology that closely involves participants in a social situation; it is necessarily strongly influenced by their values and culture, Somekh (2006). In action research, the researcher is concerned with using a systematic process in solving educational problems and making improvements (Tomal, 2010). Further, Tomal explained that in action research, the researcher is concerned with using a systematic process in solving educational problems and making improvements. Therefore the methodology used by the researcher 
was Classroom Action Research (CAR) which was classified into three categories, cycle 1 , cycle 2 , and cycle 3 . The classification of the time used in this research was 4 (four) months. Each month consists of 4 (four) weeks, and one week equals one meeting, where cycle 1 consisted of 5 (five) weeks, cycle 2 consisted of 5 (five) weeks, and cycle 3 consisted of 6 (six) weeks.

The process used by the researcher had four phases that were begun from planning, action, observation, and reflection. Each cycle was ended with 5 (five) questions in essay form, and those questions were validated by using content and face validity.

\section{Research Site and Participants}

Second Language Acquisition (SLA) constitutes a subject that gives a wide knowledge for the students how to get English as a foreign language at English Department IKIP Gunungsitoli as students whose first language is not English or non-native speaker. The participants of this research were the sixth-semester students of the English Department, consisting of 32 students.

\section{Data Collection and Analysis}

The researcher collected the data by teaching the students where one meeting applied the fourth steps of CAR, planning, action, observation, and reflection. Each cycle consisted of 5 (five) meetings, except cycle 3 consisted of 6 (six) meetings. Each meeting had a unique result because of the students participating in following the teaching and learning process were diverse. For example, the motivation of the students to fill the chart prepared was so enthusiastic. It could be seen from the students' activities had a high spirit to compete in the classroom by writing and orally. To assure the researcher whether classroom activities were running well or not, the researcher was always accompanied by a teacher collaborator and filled the form that had been prepared. At the end of each cycle, the researcher evaluated and had a reflection.

\section{FINDINGS AND DISCUSSION}

\section{Findings}

The problem appears because of the gap between reality and expectation. The main gap that the students found in studying the Second Language Acquisition (SLA) is related to the lack of comprehension of getting a message from the reading text the students read. The problem the researcher formulated, how does KWL Strategy increase the students' comprehension of SLA subject at the sixth-semester students of English Department IKIP Gunungsitoli? 
In cycle one, the materials that were studied were chapter 1 and chapter II. The researcher used the time to explain the way how to comprehend the message from the text they read by following the procedures of the KWL strategy. Classroom activities were fulfilled by reading and doing exercises to fill the chart provided with intervention from the researcher. The intervention had to be done because some students had little knowledge of following the procedures. Many students do not understand why they are involved in the learning activity. The researcher responded to the situation by creating environments that respond sensitively to students' needs until the students' behavior is positive and goal-directed (Jones \& Jone, 1998). The students always got reward when the result of their working was better.

In cycle II, the studied materials were chapter III and chapter IV. Classroom activities had good progress. The students began trying to conclude what they got from the material, and the students were able to solve the problems they found to fill the chart and began to have the independence to decide what content of each column. The students enjoyed their classroom activities because the classroom atmosphere was full of fun. For example, the students might modify the form of their chart, and they add something to the column. The students also searched the same topics from the internet to show alternative information and develop their knowledge related to their studied topic.

In cycle III, classroom activities were reading the material, and the students were able to draw the chart and fill the column with the material they read. McAllister (1994) notes the usefulness of the K-W-L in keeping track of the quantity and quality of participation of primary level compensatory students. Further, having students articulate their thoughts when solving a problem using the K-W-L format emphasizes that process is as important as the product. In this phase, the students got used to filling the column without intervention from the researcher. The students were able to connect, differentiate, and compare the information from each column to build their comprehension. The discussion played a significant role in building the students' confidence. Nagel, Blignaut, and Cronjé (2009) said that weak students generally interact and participate less than stronger students. Thus teachers should increase their level of collaboration via discussion to enhance their understanding and improve their critical thinking skills. To keep the time, the researcher asked some of the students to orally convey the result of their tasks. 
Table 1. The Result of Students'

Observation

\begin{tabular}{lllll}
\hline \multirow{2}{*}{ Students } & \multicolumn{2}{l}{ Cycle } & \multirow{2}{*}{$\mathbf{N}$} \\
\cline { 2 - 4 } & I & II & III & \\
\hline Active & 10 & 27 & 32 & \multirow{2}{*}{32} \\
\hline$\%$ & 31,3 & 81,3 & 100 & \\
\hline Inactive & 22 & 5 & - & \multirow{2}{*}{32} \\
\hline$\%$ & 68,7 & 15,7 & - & \\
\hline Cooperative & 8 & 25 & 30 & \multirow{2}{*}{32} \\
\hline$\%$ & 25 & 78,2 & 93,7 & \\
\hline Uncooperative & 24 & 7 & 2 & \multirow{2}{*}{32} \\
\hline$\%$ & 75 & 21,8 & 6,3 & \\
\hline$\%$
\end{tabular}

The result of students' observation to apply the KWL Strategy showed that active and cooperative students in cycle I did not achieve 50\% from the participants because the students were not effective in applying the procedures. Consequently, the students felt difficult to have the spirit or motivation to follow the classroom activities. In cycle II, the researcher encouraged the students to improve their understanding of filling the chart by activating their level performance and inviting them to discuss the problems they found. The researcher also encouraged the students to use the question words to guide them to think and had the perseverance to expand on ideas. Hence, the students' performance can achieve above $75 \%$, step by step inactive, and uncooperative students showed their self-confidence. For the last cycle, Classroom activities were running better, the students showed their interest in this strategy, and as a result, their attitude towards reading class had some changes. The students were aware of how important the procedures of the KWL strategy would be applied when being read. Thus, the procedures of the KWL Strategy should be familiar to the students and have the enthusiasm to do their tasks. The students could think about and reflect on their prior knowledge and develop their questions. Discussion using question words was the dominant action for the students.

At the end of each cycle, the researcher evaluated the students' achievements and analyzed the students' papers, the result as follow:

Table 2. The Students' Achievement in Reading Comprehension in SLA

\begin{tabular}{llllll}
\hline Cycle & $\mathbf{N}$ & Grading & & $\mathbf{f}$ & $\mathbf{\%}$ \\
\hline \multirow{4}{*}{ I } & & Excellent & $90-100$ & 0 & 0 \\
\cline { 3 - 6 } & & Good & $80-89$ & 0 & 0 \\
\cline { 3 - 6 } & 32 & Adequate & $70-79$ & 8 & 25 \\
\cline { 3 - 6 } & & Inadequate & $60-69$ & 17 & 53.1 \\
\cline { 3 - 6 } & & Failing & $0-59$ & 7 & 23.3 \\
\hline \multirow{4}{*}{ II } & Excellent & $90-100$ & 1 & 3.1 \\
\cline { 3 - 6 } & & Good & $80-89$ & 9 & 28.1 \\
\cline { 3 - 6 } & 32 & Adequate & $70-79$ & 21 & 65,6 \\
\cline { 3 - 6 } & & Inadequate & $60-69$ & 1 & 3,1 \\
\cline { 3 - 6 } & & Failing & $0-59$ & 0 & 0 \\
\hline \multirow{4}{*}{ III } & Excellent & $90-100$ & 5 & 15.6 \\
\cline { 3 - 6 } & 32 & Good & $80-89$ & 25 & 78.1 \\
\cline { 3 - 6 } & & Adequate & $70-79$ & 2 & 6.3 \\
\cline { 3 - 6 } & & Inadequate & $60-69$ & 0 & 0 \\
\cline { 3 - 6 } & & Failing & $0-59$ & 0 & 0 \\
\hline
\end{tabular}


Table 3. The Students' Score in Reading Comprehension in SLA

\begin{tabular}{llll}
\hline Cycle & $\begin{array}{l}\text { Highest } \\
\text { Score }\end{array}$ & $\begin{array}{l}\text { Lowest } \\
\text { Score }\end{array}$ & Average \\
\hline I & 77 & 56 & 63 \\
\hline II & 90 & 64 & 72 \\
\hline III & 95 & 81 & 83 \\
\hline
\end{tabular}

Table 2 and Table 3 illustrate the students' achievement in SLA after implementing the KWL Strategy. The result of students' achievement in the first cycle showed that most students' score was inadequate level with an average 63 . This score indicated that the students were not familiar with the procedures of the KWL Strategy. Hesitating happened in the students' minds because of difficulties in filling the charts. They could not differentiate the content of the first column, second column, and third column. The students needed the intervention to guide them to get the point from their reading text and which column should be filled.

Classroom activities in cycle two gave progress on the students' achievement, the majority of the students were inadequate level (70 $79)$, reflection on ideas to fill the charts were diverse, students began to be brave to express their ideas because of the chance they had to make questions as a part of humorous students' activities. In the classroom activities in the last cycle, most of the students were able to comprehend the reading material they read and feel interested in reading. Filling the column would help students talk about and explore their own experiences and/or feelings, which would, in turn, help them to understand the value they attached to the material being read. Most of the students' achievement was at a good level (80-89), and their average was 83 . The matter showed that the students could acquire the content they read.

The data explained that observation showed that the students' activities to follow the teaching and learning process had progressed every cycle. This matter could be seen from the active and cooperative students when they were given a chance to discuss. They were enthusiastic to follow the KWL procedures and reflect their ideas. Rogers (2002) contended that doing' reflection would be (1) a 'meaning-making process', (2) a 'systematic, rigorous, and disciplined way of thinking', (3) an activity that takes place 'in community, in interaction with others', and (4) drawn to 'attitudes that value the personal and intellectual growth of oneself and others. In Rogers' opinion, reflection emphasized that the students' mindset should be changed from inactive to be active and from uncooperative to be cooperative. By doing this, it would probably be the effective interaction 
that happened between them and could bear the positive achievement.

\section{Discussion}

The role of intervention in KLW Strategy in comprehending SLA

At the beginning of teaching SLA, the intervention was necessary because the procedures of the KWL Strategy were not familiar for the students, the discussion was not running well, inactive and uncooperative were seen in the classroom situation. That's why the intervention was being applied to encourage the students to be active and cooperative by the purpose, they initiate and intensify cooperation among them. They initiated to make questions to fill the column they owned.

An intervention is any action initiated to create a more positive way for the students to interact. According to Al Safadi (2014), intervention strategies are the systematic instructions to promote progress in an area where there is a need for classroom activities. Ajen (2019) stated that intervention designed to change behavior could be directed at one or more of its determinant: attitudes, subjective norms, or perception of behavior control. Interventions focus on the person as a subject and understand how people make sense of their worlds and then act, Madoc-Jones (2008). The intervention in teaching SLA was needed for students with a vague point of view of KWL procedures or negative attitudes.

An intervention can be thought of as "a set of actions that, when taken, have demonstrated the ability to change a fixed educational trajectory" (Methe \& Riley-Tillman, 2008). As an example of academic intervention, the teacher may select question generation (Davey \& McBride, 1986; Rosenshine et al., 1996), a strategy in which the student is taught to locate or generate main idea sentences for each paragraph in a passage and record those 'gist' sentences for later review.

\section{Students' Motivation in Studying SLA with K W L Strategy}

Motivation is one of the most crucial predictive factors of foreign/second (L2) language learning achievement. Motivation is a power that should be owned by the students to perform or accomplish a task. Motivation can come from within (internal) or outside (external). Internal motivation is what learners themselves bring into the learning environment like attitudes, needs, personality factors, and values. In contrast, external motivation originates in the learning environment, where persons are offered the right incentives for doing a certain 
thing. The use of rewards represents a reinforcement approach to motivation, Moore, Kenneth D. (2005). Motivation influences achievement (e.g., Ahmed et al., 2010; Cleary \& Chen, 2009; Reynolds, 1991; Shores \& Shannon, 2007; Steinmayr \& Spinath, 2009; Woolley et al., 2010).

\section{Applying fluency in reading comprehension of SLA with $K W L$ Strategy}

The students' fluency in reading comprehension of SLA is a key factor and adequate improvement in learning to read. Developing fluency in reading is very important to achieve comprehension (Lems et al., 2010). Thus, fluency is part of the developmental reading process in which readers move beyond word recognition to begin to stitch together meanings across words. This linking function is sometimes called a "bridge" between decoding words and comprehension of connected text (Nation, 2009). Fluency development involves making the best use of what is already known. The best-known kind of fluency development is speed reading, where learners focus on increasing their reading speed while maintaining good comprehension.

According to Serravallo (2010), fluency is vital to signal the extent to which a reader makes sense of the text as he reads. Fluency tells us about comprehension. A reader also communicates that meaning to a listener through reading smoothly and expressively. Fluency affects comprehension, and comprehension affects fluency (Kuhn, 2008; Rasinski, 2003). Furthermore, Khataee (2019) quoted several results of studies that stated that many factors affect reading comprehension, for example, fluency, word recognition, memory vocabulary, and grammar.

\section{The role of vocabulary in reading comprehension of SLA with $K W \mathrm{~L}$ Strategy}

It is impossible for the students without the knowledge of vocabulary in comprehending SLA Material. The knowledge of vocabulary is as a bridge for the students to comprehend the reading text. Vocabulary knowledge is strongly linked to reading comprehension (Freebody \& Anderson, 1983), and there is reason to believe that vocabulary knowledge is an especially important factor in understanding the reading problems experienced by second-language learners (García, 1991; Laufer \& Sim, 1985). Regarding the importance of vocabulary, O'Malley and Chamot (1990) believe that vocabulary knowledge in second/foreign language learning is of paramount importance in as much as it 
is underpinned by a schema-based approach to language learning, which deals with information processing. According to Tozcu and Coady (2004), acquiring adequate vocabulary knowledge is one of the significant issues that enhance reading comprehension. The students' ability to master vocabulary may determine how they comprehend their reading text. The more students have the vocabulary, the more information they acquire.

\section{CONCLUSIONS AND SUGGESTION}

KWL is intended to be an exercise for students to guide them in reading and understanding a text. It was effective in improving participants' motivation for learning SLA subjects. The relationship between achievement and motivation was also significant and positive due to the use of the KWL strategy, where the students who owned a strong motivation to get a high score. The strategy may work well as a pre-assessment tool because it reveals what students know and want to learn about a topic before instruction. As a post-assessment tool, they all started developing their questions because it fosters reflection after the experiences, requiring students to teach and express their thoughts.

Moreover, by providing a place for question development both before and during reading, the students said they felt forced to think of questions while reading to fill in the KWL worksheet, as they did not want any empty spaces. The result of this research is KWL strategy can increase the students' reading comprehension on Second Language Acquisition (SLA) subject by applying some modifications to the procedures. This finding was in line with Mustafa and Muhammad (2016) conducted a study aimed to know the effect of K.W.L upon achievement in Islamic Education in Mecca in Saudi Arabia. The researcher used a quasiexperimental design using 2 groups (experimental and control groups). The results showed that the experimental group who taught using K.W.L had higher achievement than the control group. Considering the result from the research, the researcher recommends that the KWL strategy should be continuously implemented in activating students' reading comprehension by considering the motivation, fluency and the knowledge of students' vocabulary.

\section{REFERENCES}

Ahmed, W., Minnaert, A., van der Werf, G., \& Kuyper, H. (2010). Perceived Social Support and Early Adolescents' Achievement: The Mediational Roles of Motivational Beliefs and Emotions. Journal of Youth and 
Adolescence, $\quad 39(1), \quad 36-46$. https://doi.org/10.1007/s10964008-9367-7

Ajen, I. (2019). Behavioral Intervention Based on the theory of planned behavior.

Akyol, H. (2013). Türkçe ilkokuma yazma ögretimi. Pegem Amoi.

Al-wazzan, K. M. (2020). The Efficienc of Using KWL Strategy in Teaching Arabic for Speakers of Other languages. International Journal of English and Education, 9(3), 164-173.

Alsoudi, K. A. (2017). The Effect of Using K.W.L Strategy upon Acquiring Religious Concepts. Tafila Technical University.

Aseeri, M. M. Y. (2020). Effectiveness of Using KWL Strategy in Teaching Mathematics on the Achievement and Motivation of High School Students in Najran City, KSA. Journal of Research \& Method in Education (IOSR-JRME), 10(5), 0715.

Bachman, L. F. (1990). Fundamental Considerations in Language Testing (2nd Editio). OUP Oxford.

Bachman, L. F., \& Palmer, A. S. (2009). Language Testing in Practice: Designing and Developing Useful Language Tests. Oxford University Press.

Backman, L. O., \& Klinglammer, S. (2006). Shaping The Way We Teach. The office of English Language Programs: United States
Department of State, Washington, Dc.

Blachowicz, C. L., \& Ogle, D. (2008). Reading Comprehension: Strategies for Independent Learners (2nd editio). Guilford Press.

Carroll, J. B. (1993). Human cognitive abilities: A survey of factor-analytic studies. Cambridge University Press.

Casey. (2009). Using KWL strategies in reading for students with autism. http://www.brighthub.com/edu cation/special/topics/autism.asp $\mathrm{x}$

Castles, A., Rastle, K., \& Nation, K. (2018). Ending the Reading Wars: Reading Acquisition From Novice to Expert. Psychological Science in the Public Interest, 19(1), 5-51. https://doi.org/10.1177/1529100 618772271

Clarke, P. J., Truelove, E., Hulme, C., \& Margaret, J. S. (2014). Developing Reading Comprehension (First Edit). John Wiley \& Sons, Ltd.

Cleary, T. J., \& Chen, P. P. (2009). Selfregulation, motivation, and math achievement in middle school: Variations across grade level and math context. Journal of School Psychology, 47(5), 291-314. https://doi.org/10.1016/j.jsp.200 9.04 .002

Connolly, S. (2007). Successful Strategies for Reading in the Content Areas Grades 305. Shell Education. 
Davey, B., \& McBride, S. (1986). Effects of Question-Generation Training on Reading Comprehension. Journal of Educational Psychology, 78, 256-262.

Escudero, I., Fuertes, N., \& López, L. (2018). Paraphrasing Strategy in EFL Ecuadorian B1 Students and Implications on Reading Comprehension. English Language Teaching, 12(1), 56. https://doi.org/10.5539/elt.v12n $1 \mathrm{p} 56$

García, G. E. (1991). Factors Influencing the English Reading Test Performance of Spanish-speaking Hispanic Children. Reading Research Quarterly, 26(4), 371-392.

Garcia, R. A., \& Al-Safadi, L. A. (2014). Intervention Strategies for the Improvement of Students' Academic Performance in Data Structure Course. International Journal of Information and Education Technology, 4(5).

Glenberg, A. M. (2017). How reading comprehension is embodied and why that matters. International Electronic Journal of Elementary Education, 4(1), 5-18.

Hashimi, A., \& Delemi, T. (2008). Modern Strategies in the Art of Teaching. Dar Alshorok.

Jones, V. F., \& Jone, L. S. (1998). Comprehensive Classroom Management. Creating Communities of Support and Solving Problems. Allyn and Bacon.
Kadem, R. (2020). Investigating Teachers' Attitude towards the Role of KWL Strategy in Enhancing EFL Learners' Reading Comprehension. Larbi Ben M'hidi University.

Kadhim, S. H. (2019). The Effect of Applying K-W-L Technique on Teaching ESP Students. University of Baghdad, Iraq Khanyounis Governorate Schools. Al-Azhar University.

Khataee, E. (2019). The Effect of THIEVES Strategy on EFL Learners' Reading Comprehension. International Journal of Instruction. www.eiji.net

Kintsch, W., \& Kintsch, E. (2005). Comprehension (S. Stahl \& S. Paris (eds.)).

Kuhn, M. (2008). The Hows and Whys of Fluency Instruction. AddisonWesley.

Laufer, B., \& Sim, D. D. (1985). Measuring and Explaining the Reading Threshold Needed for English for Academic Purposes Texts. Foreign Language Annals, 18(5), 405-411.

Lems, K., Miller., L. D., \& Soro, T. M. (2010). Teaching Reading to English Language Learners. Insights from Linguistics. The Guilford Press.

Madoc-Jones, I. (2008). Models of Intervention. In S. Green, E. Lancaster, \& S. Feasey (Eds.), Addressing Offending Behaviour 
Context, practice, and values (pp. 128-153). Willan Publishing.

McAllister, P. J. (1994). Using K-W-L for informal assessment. The Reading Teacher, 47, 510-511.

McNamara, D. S. (2012). Reading Comprehension Strategies: Theories, Inventions, and Technologies. Psychology Press.

Meniado, J. C. (2016). Metacognitive Reading Strategies, Motivation, and Reading Comprehension Performance of Saudi EFL Students. English Language Teaching, $\quad 9(3), \quad 117$. https://doi.org/10.5539/elt.v9n3 p117

Methe, S. A., \& Riley-Tillman, T. C. (2008). An informed approach to selecting and designing early mathematics interventions. School Psychology Forum: Research into Practice, 2, 29-41.

Moore, K. D. (2005). Effective Instructional Strategies From Theory to Practice. Sage Publications, Inc.

Mustafa, F., \& Muhammad, F. (2016). The effect K.W.L. on achievement among 9th-grade students reading and knowledge. Journal Einshams University, 178, 57-166.

Nagel, L., Blignaut, A. S., \& Cronjé, J. C. (2009). Read-only participants: a case for student communication in online classes. Interactive Learning Environments, 17(1), 3751. https://doi.org/10.1080/1049482 0701501028

Nation, I. S. P. (2009). Teaching ESL/EFL Reading and Writing. Routledge.

Nofal, M. (2007). Multiple intelligences in the classroom. Dar Almasira.

O'Malley, A. U., \& Chamot, M. (1990). Learning Strategies in Language Acquisition. Cambridge University Press.

Oakley, G. (2011). The Assessment of Reading Comprehension Cognitive Strategies: Practices and Perceptions of Western Australian Teachers. Australian Journal of Language and Literacy, 34, 279-292.

Protacio, M. S. (2017). A Case Study Exploring the Reading Engagement of Middle Grades English Learners. RMLE Online, 40(3), 1-17. https://doi.org/10.1080/1940447 6.2017.1280586

Rapp, D. N., \& van den Broek, P. (2005). Dynamic Text Comprehension: An Integrative View of Reading. Current Directions in Psychological Science, 14, 276-279.

Rasinski, T. (2003). The Fluent Reader: Oral Reading Strategies for Building Word Recognition, Fluency, and Comprehension. Scholastic.

Reynolds, A. J. (1991). The Middle Schooling Process: Influences on Science and Mathematics Achievement from the Longitudinal Study of American 
Youth. Adolescence, 26(101), 133158.

Rodgers, C. (2002). Defining reflection: Another look at John Dewey and reflective thinking. Teachers College Record, 104(4), 842-866.

Roe, B., Smith, S., \& Burns, P. C. (2011). Teaching Reading in Today's Elementary Schools (11th editi). Cengage Learning.

Rosenshine, B., Meister, C., \& Chapman, S. (1996). Teaching students to generate questions: A review of the intervention studies. Review of Educational Research, 66, 181-221.

Serravallo, J. (2010). Teaching Reading in Small Groups Differentiated Instruction for Building Strategic, Independent Readers. Heinemann.

Shores, M. L., \& Shannon, D. M. (2007). The Effects of Self-Regulation, Motivation, Anxiety, and Attributions on Mathematics Achievement for Fifth and SixthGrade Students. School Science and Mathematics, 107(6), 225-236. http://ssmj.tamu.edu

Snow, C. (2002). Reading for Understanding: Toward an RED Program in Reading Comprehension. RAND Corporation.

Somekh, B. (2006). Action Research: a Methodology for Change and Development. Open University Press McGraw-Hill Education.

Steinmayr, R., \& Spinath, B. (2009). The importance of motivation as a predictor of school achievement. Learning and Individual Differences, 19(1), 80-90. https://doi.org/10.1016/j.lindif.2 008.05.004

Thi Thanh Dieu, T. (2015). Trying K-WL Strategy on Teaching Reading Comprehension to Passive Students in Vietnam. International Journal of Language and Linguistics, 3(6), 481. https://doi.org/10.11648/j.ij1l.20 150306.33

Tomal, D. R. (2010). Action Research for Educators (2nd Editio). Rowman \& Littlefield Education.

Torgesen, J. K. (2000). Individual Differences in Response to Early Intervention in Reading: The Lingering Problem of Treatment Resisters. Learning Disabilities Research and Practice, 15(1), 55-64.

Tozcu, A., \& Coady, J. (2004). Successful Learning of Frequent Vocabulary through CALL also Benefits Reading Comprehension and Speed. Computer Assisted Language Learning, 17(5), 473-495. https://doi.org/10.1080/0958822 042000319674

Troike, M. S. (2012). Introducing Second Language Acquisition (2nd Editio). Cambridge University Press.

Van den Broek, P., Kendeou, P., Kremer, K., Lynch, J. S., Butler, J., White, M. J., \& Lorch, E. P. (2005). Assessment of Comprehension Abilities in Young Children. In S. Stahl \& S. Paris (Eds.), Children's 
Reading Comprehension and Woolley, M. E., Strutchens, M. E., Assessment (pp. 107-130). Gilbert, M. C., \& Martin, W. Lawrence Erlbaum Associates, Inc. (2010). Mathematics success of black middle school students: Direct and indirect effects of

Vy, L. T. T., \& Ha, N. T. T. (2020). The effect of the KWL strategy on Vietnamese fifth-grade students' reading comprehension achievement at Vstar school. SOCIAL SCIENCES, 10(1), 67-78. https://doi.org/10.46223/HCMC OUJS.soci.en.10.1.547.2020

Westwood, P. (2001). Reading and Learning Difficulties; Approaches to Teaching and Assessment. The Australian Council for Educational Research Ltd. teacher expectations and reform practices. Negro Educational Review, 61(1-4), 41-59.

Youniss, M. M. A. (2013). The Effectiveness of Using (K.W.L) Strategy on Developing Reading Comprehension Skills for the Eighth Graders in Khanyounis Governorate Schools. Al-Azhar UniversityGaza.

Zimmermann, S., \& Hutchins, C. (2003). Seven Keys to Comprehension: How to Help Your Kids Read it and Get it. Three Rivers Press. 